\title{
Inhibitory effects of antagonistic analogs of GHRH on GH3 pituitary cells overexpressing the human GHRH receptor
}

\author{
M Kovacs ${ }^{1,2}$, A V Schally ${ }^{1,2}$, E-J Lee ${ }^{3}$, R Busto $^{1,2}$, P Armatis ${ }^{1}$, \\ K Groot ${ }^{1}$ and J L Varga ${ }^{1,2}$ \\ ${ }^{1}$ Endocrine, Polypeptide, and Cancer Institute, Veterans Affairs Medical Center, New Orleans, Louisiana 70112, USA \\ ${ }^{2}$ Section of Experimental Medicine, Department of Medicine, Tulane University School of Medicine, New Orleans, Louisiana 70112, USA \\ ${ }^{3}$ Division of Endocrinology, Metabolism, and Molecular Medicine, Northwestern University Medical School, Chicago, Illinois 6061, USA \\ (Requests for offprints should be addressed to A V Schally, Veterans Administration Medical Center, 1601 Perdido Street, New Orleans, \\ Louisiana 70112, USA) \\ (M Kovacs is now at Department of Human Anatomy, University of Pecs, Medical School, 7643 Pecs, Hungary)
}

\begin{abstract}
GH3 rat pituitary tumor cells produce $\mathrm{GH}$ and prolactin (PRL), but lack the GHRH receptor (GHRH-R). We expressed human GHRH-R (hGHRH-R) in GH3 cells using recombinant adenoviral vectors and studied the effects of GHRH antagonists. The mRNA expression of the GHRH-R gene in the cells was demonstrated by RT-PCR. An exposure of the GH3 cells infected with hGHRH-R to $10^{-10}, 10^{-9}$ and $10^{-8} \mathrm{M}$ hGHRH for 1 or $2 \mathrm{~h}$ in culture caused a dose-dependent elevation of the intracellular cAMP concentration and the cAMP efflux. Exposure to hGHRH also elicited dose-dependent increases in GH and PRL secretion from these cells. Neither the uninfected nor the antisense hGHRH-Rinfected control cells exhibited cAMP, GH and PRL responses to GHRH stimulation. GHRH antagonists JV-1-38 and JV-1-36 applied at $3 \times 10^{-8} \mathrm{M}$ for $3 \mathrm{~h}$, together with $10^{-9} \mathrm{M}$ GHRH, significantly inhibited the GHRH-stimulated cAMP efflux from the hGHRH-R-
\end{abstract}

infected cells by 36 and $80 \%$ respectively. The more potent antagonist JV-1-36 also decreased the intracellular cAMP levels in these cells by 55\%. Exposure to JV-1-36 for $1 \mathrm{~h}$ nullified the stimulatory effect of GHRH on $\mathrm{GH}$ secretion and significantly inhibited it by 64 and $77 \%$ after 2 and 3 h respectively. In a superfusion system, GHRH at $10^{-10}, 10^{-9}$ and $10^{-8} \mathrm{M}$ concentrations induced prompt and dose-related high cAMP responses and smaller increases in the spontaneous $\mathrm{GH}$ secretion of the hGHRH-R-infected cells. Antagonists JV-1-36 and JV1-38 applied at $3 \times 10^{-8} \mathrm{M}$ for $15 \mathrm{~min}$, together with $10^{-9} \mathrm{M}$ GHRH, inhibited the GHRH-stimulated cAMP response by 59 and 35\% respectively. This work demonstrates that GHRH antagonists can effectively inhibit the actions of GHRH on the hGHRH-R. Our results support the view that this class of compounds would be active clinically.

Journal of Endocrinology (2002) 175, 425-434

\section{Introduction}

Various experimental and clinical findings demonstrate the essential role of growth hormone $(\mathrm{GH})$-releasing hormone $(\mathrm{GHRH})$ in the control of secretion of $\mathrm{GH}$ and the regulation of linear growth (Clark \& Robinson 1985, Thorner et al. 1985, Kovacs et al. 1994, 1996, Mayo et al. 1995). Diverse antagonistic analogs of GHRH have been developed in view of a strong interest in their clinical applications (Schally \& Varga 1999, Schally et al. 2001).

Robberecht et al. (1985) originally showed that an early and relatively weak GHRH antagonist, [Ac-Tyr ${ }^{1}$,D$\mathrm{Arg}^{2}$ ]hGHRH(1-29) $\mathrm{NH}_{2}$, could inhibit the GHRHstimulated adenylate cyclase activity in rat pituitary cells. A clinical study with this antagonist demonstrated a 60-70\% suppression of the GH hypersecretion in a patient with acromegaly due to a metastatic GHRH-secreting carcinoid tumor (Jaffe et al. 1997). Subsequently, GHRH antagonists with greatly increased potency were synthesized in our laboratory (reviewed in Schally \& Varga 1999).

GHRH antagonists were thought to be useful for the treatment of disorders caused by excessive GHRH and/or GH production, such as acromegaly of hypothalamic origin, diabetic retinopathy or diabetic nephropathy (Schally \& Varga 1999). A development of progressive hyperplasia of somatotrophs and adenomatous transformation under chronic stimulation by human GHRH (hGHRH) was shown in transgenic mice expressing hGHRH gene, an animal model of human acromegaly caused by excessive GHRH secretion (Mayo et al. 1988). Using this model, we demonstrated that GHRH 
antagonists suppressed the release of $\mathrm{GH}$ and insulin-like growth factor-I (IGF-I) (Kovacs et al. 1997a). This suggests that GHRH antagonists could be used clinically in disorders characterized by excessive GHRH secretion. An even more important indication for GHRH antagonists might be the treatment of various cancers. Many recent studies show that GHRH antagonists can inhibit tumor growth by several mechanisms. The antitumor effects of GHRH antagonists were initially thought to be exerted only indirectly through the inhibition of the release of $\mathrm{GH}$ from the pituitary, which results in the suppression of hepatic IGF-I production and the reduction in serum IGF-I levels (Schally \& Varga 1999). This indirect mechanism is important for those cancers that depend on IGF-I as a growth factor (Schally \& Varga 1999). A strong positive association was reported between plasma IGF-I levels and the risk of prostatic, breast and colorectal cancers (Chan et al. 1998, Schally et al. 2001). In nude mice bearing human prostatic, renal or other cancer lines and osteosarcomas, tumor inhibition induced by GHRH antagonists was accompanied by a decrease in levels of serum IGF-I (Pinski et al. 1995, Schally \& Varga 1999, Schally et al. 2001). However, this indirect mechanism alone could not account for tumor suppression observed in other cancer models in which GHRH antagonists did not cause a significant reduction of serum IGF-I levels. The inhibition of the proliferation of various human cancer cell lines cultured in vitro and suppression of the production of IGF-II suggested that the antagonists of GHRH must also exert some direct effect on tumors. IGF-II, like IGF-I, is a potent mitogen for many cancers and the suppression of its production would inhibit tumor growth, but unlike IGF-I, its synthesis is not controlled by GH (Schally \& Varga 1999). Thus, GHRH antagonists inhibited the production of IGF-I and IGF-II and the expression of mRNA for IGF-II in vitro and in vivo in many human cancer lines, including prostatic, pancreatic and colorectal cancers (Lamharzi et al. 1998, Szepeshazi et al. 2000a,b). Still other results demonstrated the expression of mRNA for GHRH and the presence of biologically active GHRH in human prostatic and breast cancers, and small-cell lung carcinoma (SCLC) (Kahan et al. 1999, 2000, Kiaris et al. 1999, Halmos et al. 2002). This suggests that GHRH can function as an autocrine growth factor (Schally et al. 2001). In some human cancer models such as H-69 SCLC, the tumor inhibition induced by GHRH antagonists was not associated with any significant changes in IGF-I and IGF-II (Kiaris et al. 1999) and the effects of GHRH antagonists could be due to the blockade of the stimulatory action of tumoral autocrine GHRH. A direct action of GHRH antagonists on tumor growth would have to be mediated through specific GHRH receptors (GHRH-Rs) on tumors. The recent demonstration of mRNA for splice variants of GHRH-R in various human cancers, including prostatic, pancreatic, renal, breast and ovarian, indicates that the direct inhibitory effects of GHRH antagonists might be mediated by these tumoral GHRH-Rs that are different from those found in the pituitary (Halmos et al. 2000, 2002, Rekasi et al. 2000a).

GHRH antagonists JV-1-36 and JV-1-38, developed recently in our laboratory, exhibit a high binding affinity to rat pituitary GHRH-R and strongly inhibit the GHRH-evoked GH release from rat pituitaries in vivo and in vitro (Varga et al. 1999). The antiproliferative effects of these antagonists on various human cancer cells expressing the splice variants of GHRH-R were also demonstrated in recent studies (Rekasi et al. 2000b, 2001, Schally et al. 2001). However, the activity of these GHRH analogs on the human pituitary GHRH-R has not been evaluated. The aim of this study was to demonstrate the efficacy of antagonists JV-1-36 and JV-1-38 on the human pituitary receptor. Since human pituitary tissue is not available for research, we infected the GH3 rat pituitary tumor cell line that produces $\mathrm{GH}$ with adenoviral vector carrying human GHRH-R (hGHRH-R), as in a previous study (Lee et al. 2001). We then utilized GH3 cells expressing hGHRH-R to evaluate the effects of GHRH antagonists on the cAMP, GH and prolactin (PRL) secretion.

\section{Materials and Methods}

\section{Peptides}

hGHRH(1-29) $\mathrm{NH}_{2}$ (GHRH), and GHRH antagonists $\left[\mathrm{PhAc}-\mathrm{Tyr}^{1}, \mathrm{D}-\mathrm{Arg}^{2}, \mathrm{Phe}(4-\mathrm{Cl})^{6}, \mathrm{Arg}^{9}, \mathrm{Abu}^{15}, \mathrm{Nle}^{27}, \mathrm{D}-\right.$ $\mathrm{Arg}^{28}{ }^{28} \mathrm{Har}^{29}$ hGHRH(1-29) $\mathrm{NH}_{2}$ (JV-1-36) and [PhAc$\mathrm{Tyr}^{1}, \mathrm{D}-\mathrm{Arg}^{2}, \mathrm{Phe}(4-\mathrm{Cl})^{6}, \mathrm{Har}^{9}, \mathrm{Tyr}(\mathrm{Me})^{10}, \mathrm{Abu}^{15}, \mathrm{Nle}^{27}, \mathrm{D}-$ $\mathrm{Arg}^{28}, \mathrm{Har}^{29}$ ]hGHRH(1-29) $\mathrm{NH}_{2}$ (JV-1-38) were synthesized in our laboratory by solid-phase methods and purified as described (Varga et al. 1999).

\section{Recombinant adenoviral vectors and infection of $\mathrm{GH} 3$ cells}

GH3 cells were obtained from the American Type Culture Collection (Manassas, VA, USA). The recombinant adenoviral vectors carrying the hGHRH-R (AdGHRH-R) and the antisense hGHRH-R (AdAS) were described previously (Lee et al. 2001). Transduction efficiency of adenoviral vectors was tested in GH3 cells using AdCMVGal (Lee et al. 1999). $\beta$-Galactosidase gene expression was detected in $95-100 \%$ of GH3 cells at $48 \mathrm{~h}$ after infection with 5 plaque forming units/cell of AdCMVGal. Therefore, subsequent experiments were performed using the same concentration of AdGHRH-R or AdAS. Twenty-four hours after infection of GH3 cells with adenoviral vectors, cells were collected and frozen in liquid nitrogen until used for the experiments to test the efficacy of GHRH or GHRH antagonists on the hGHRH-R.

\section{RNA extraction and RT-PCR for $h \mathrm{GHRH}-\mathrm{R}$}

Total RNA was extracted from AdAS-infected control, intact control and AdGHRH-R-infected GH3 cells by 
using Tri-Reagent (Sigma, St Louis, MO, USA) according to the manufacturer's instructions. The concentration of RNA was determined spectrophotometrically at $260 \mathrm{~nm}$. One microgram of total RNA was reverse transcribed and amplified using the reagents and protocol of the GeneAmp RNA PCR Core Kit (Perkin Elmer, Norwalk, CT, USA). Four microliters of cDNA were amplified by PCR in a $20 \mu \mathrm{l}$ mixture containing $1 \times$ PCR buffer, $2 \mathrm{mM}$ $\mathrm{MgCl}_{2}, 200 \mu \mathrm{M}$ of each dNTP, $0.5 \mu \mathrm{M}$ of each primer (for hGHRH-R), $0 \cdot 15 \mu \mathrm{M}$ of each primer (for $\beta$-actin), and $2.5 \mathrm{U} / 100 \mu \mathrm{l}$ Amplitaq DNA polymerase. PCR consisted of 1 cycle at $95^{\circ} \mathrm{C}$ for 3 min, followed by 30 cycles of $95{ }^{\circ} \mathrm{C}$ for $30 \mathrm{~s}, 60^{\circ} \mathrm{C}$ for $45 \mathrm{~s}$, and $72{ }^{\circ} \mathrm{C}$ for $1 \mathrm{~min}$ for hGHRH-R; or $95^{\circ} \mathrm{C}$ for $90 \mathrm{~s}$, followed by 30 cycles of $95^{\circ} \mathrm{C}$ for $15 \mathrm{~s}$ and $60^{\circ} \mathrm{C}$ for $30 \mathrm{~s}$ for $\beta$-actin, and a final extension at $72{ }^{\circ} \mathrm{C}$ for $7 \mathrm{~min}$. The primers used were $5^{\prime}$-ATG GGC TGC TGT GCT GGC CAA C-3' (sense) and 5'-TAA GGT GGA AAG GGC TCA GAC C-3' (antisense) for hGHRH-R (Rekasi et al. 2000a); and the primers for $\beta$-actin were described previously (Kovacs et al. 2002). The PCR products were electrophoresed on $1 \cdot 8 \%$ agarose gel and stained with ethidium bromide.

\section{GH3 cell cultures}

GH3 cells kept in liquid nitrogen were thawed $24 \mathrm{~h}$ before the experiments. The cells were grown for one passage in DMEM/Ham's F-12 containing 10\% fetal bovine serum (FBS) (Atlanta Biologicals, Norcross, GA, USA) and divided into aliquots of $1.1 \times 10^{6}$ cells. The cell culture medium was supplemented with $100 \mathrm{U} / \mathrm{ml}$ penicillin and $100 \mu \mathrm{g} / \mathrm{ml}$ streptomycin, and the cultures were maintained at $37^{\circ} \mathrm{C}$ in a humidified atmosphere containing 95\% air $/ 5 \% \mathrm{CO}_{2}$.

In Experiment 1, to evaluate whether the hGHRH-R transferred to GH3 cells by adenoviral vector mediates signal transduction and restores hormone secretion in response to GHRH, we investigated cAMP, GH and PRL responses of the hGHRH-R-infected and control cells to GHRH. Before applying GHRH, the cells were treated with isobutylmethylxanthine for $20 \mathrm{~min}$ at $37^{\circ} \mathrm{C}$, to block phosphodiesterase activity and preserve cAMP levels. Triplicate aliquots of AdGHRH-R-infected, AdASinfected control, and intact control GH3 cells were exposed to $10^{-10}, 10^{-9}$ and $10^{-8} \mathrm{M}$ GHRH dissolved in fresh warm medium or to medium alone as control, and incubation was continued for $120 \mathrm{~min}$ at $37^{\circ} \mathrm{C}$. After 30 , 60 and $120 \mathrm{~min}, 50 \mu \mathrm{l}$ samples were taken from the incubation media, and GH and PRL concentrations were determined by RIA. cAMP concentration in the incubation media at $120 \mathrm{~min}$ was also determined. At the end of the experiment, the medium was removed and $0.5 \mathrm{ml}$ ice-cold $0.1 \mathrm{M} \mathrm{HCl}$ was added to each aliquot and harvested. Cell lysates were centrifuged for $10 \mathrm{~min}$ at $4{ }^{\circ} \mathrm{C}$ to remove protein. The supernatants were neutralized with an equal volume of $150 \mathrm{mM}$ Tris- $\mathrm{HCl}$ buffer $(\mathrm{pH}$
8.6) containing $4 \mathrm{mM}$ EDTA, and intracellular cAMP concentrations were determined.

In Experiment 2, we tested the ability of GHRH antagonists to inhibit the stimulatory effects of GHRH mediated by the hGHRH-R. Quadruplicate aliquots of AdGHRH-R-infected, AdAS-infected control, and intact control GH3 cells were exposed to $3 \times 10^{-8} \mathrm{M} \mathrm{GHRH}$ antagonists JV-1-36 or JV-1-38, and to medium as control. After an incubation for $10 \mathrm{~min}, 10^{-9} \mathrm{M}$ GHRH or medium (control) was added to the wells, and incubation was continued for $3 \mathrm{~h}$. All peptides were dissolved in fresh warm medium. At 1, 2 and $3 \mathrm{~h}$ of incubation $50 \mu \mathrm{l}$ samples were taken from the incubation media and used for GH determination. cAMP concentration in the incubation media at $3 \mathrm{~h}$ was also determined. After finishing the experiment, cell lysates were obtained as described in Experiment 1, and cAMP concentrations were determined by RIA.

\section{Superfused GH3 cell system}

To study the time-course of cAMP and GH responses to GHRH stimulation, experiments were performed in a dynamic superfusion system. This system was similar to that described earlier for studying the antagonistic activity of the GHRH analogs on the dispersed pituitary cells (Horvath et al. 1995, Kovacs et al. 1996, 1997b). In brief, cultured cells were harvested, resuspended in $2 \mathrm{ml}$ tissue culture medium DMEM containing 10\% FBS and antibiotics, as described for cell cultures, and 2.5-3.0 $\times 10^{7}$ cells were transferred into the chambers of the superfusion apparatus. The cells were allowed to sediment simultaneously with $1 \mathrm{ml}$ Sephadex-G-10 equilibrated with medium and continuously perfused with medium at a flow rate of $1 \mathrm{ml} / 3 \mathrm{~min}$. To ensure stable baseline values, the experiment was started after a recovery period of $2 \mathrm{~h}$. Three chambers of the superfusion system, containing AdGHRH-R-infected, AdAS-infected control, and intact control cells, were used in each experiment. To investigate the time-course of cAMP and GH responses to GHRH stimulation mediated by the hGHRH-R, the cells were subsequently perfused with $10^{-10}, 10^{-9}$ and $10^{-8} \mathrm{M}$ GHRH for $30 \mathrm{~min}$ at $90 \mathrm{~min}$ intervals, and $3 \mathrm{~min}$ fractions of the effluent medium were collected and used for cAMP and $\mathrm{GH}$ determinations. At the beginning and the end of the experiments, the membrane-depolarizing $\mathrm{K}^{+}(25 \mathrm{mM}$ $\mathrm{KCl}$ ) was administered for 3 min to check the amount of releasable hormone in the cells. In other experiments, the inhibitory effects of GHRH antagonists JV-1-36 and JV-1-38 on the GHRH-stimulated cAMP production and $\mathrm{GH}$ secretion of the infected cells were tested. In these tests, AdGHRH-R-infected cells were used in all three chambers of the superfusion apparatus. After the initial pulse of $\mathrm{K}^{+}, 10^{-9} \mathrm{M}$ GHRH was applied for $15 \mathrm{~min}$, and the response was used as reference. Ninety minutes later, the cells were exposed to GHRH antagonist JV-1-36 or 
JV-1-38 for $9 \mathrm{~min}$, followed by a co-administration of $10^{-9} \mathrm{M}$ GHRH and $3 \times 10^{-8} \mathrm{M}$ antagonist for $15 \mathrm{~min}$. To check the recovery of the GHRH-R from inhibition, two additional $10^{-9} \mathrm{M}$ GHRH stimuli were applied at $60 \mathrm{~min}$ intervals for $15 \mathrm{~min}$. A control chamber, with AdGHRH-R-infected cells, was perfused with $10^{-9} \mathrm{M}$ GHRH alone at intervals corresponding to the GHRH exposure of the antagonist-treated cells. cAMP and GH concentrations in the $3 \mathrm{~min}$ fractions were determined by RIA. cAMP and GH responses to the antagonist treatment were compared with the first response to GHRH (reference response) and the corresponding responses to GHRH in the control chamber.

\section{RIA}

For cAMP determinations, a freshly prepared mixture of triethylamine and acetic anhydride $(2: 1 \mathrm{v} / \mathrm{v})$ was added to ice-cold aliquots of the medium fractions and cell lysates $(1: 20)$, and these aliquots were kept frozen at $-20{ }^{\circ} \mathrm{C}$. cAMP concentration of the acetylated samples was determined by double-antibody RIA as described (Csernus et al. 1999). The antiserum for cAMP was obtained from US National Institute of Diabetes and Kidney Diseases (Rockville, MD, USA) (CV-27), while the standard cAMP and 2'-monosuccinyl-cAMP tyrosyl methyl ester for iodination were purchased from Sigma.

$\mathrm{GH}$ concentrations in the superfusion and cell culture aliquots as well as PRL in the culture media were measured by double-antibody method using materials supplied by the US National Hormone and Pituitary Program, Rockville, MD, USA (rat GH-RP2/AFP-3190B, rat GH-I-6/AFP-5676B, anti-rat GHRIA-5/AFP411S, rat PRL-RP-3/AFP-4459B, rat PRL-I-6/AFP-10505B, and anti-rat PRL-S-9/AFP$131581570)$. Interassay variation was $<15 \%$ and intra-assay variation $<10 \%$.

\section{Statistical analysis of data}

RIA results from the experiments in cell cultures are expressed as means \pm S.E.M. or mean percent of controls \pm S.E.M. of three or four values in each group. Data were subjected to one-way ANOVA, followed by a Tukey test. A $P$ value less then 0.05 was considered significant. The superfusion data were analyzed with a computer program developed in our institute (Csernus \& Schally 1991). In brief, the program first separates the fractions containing a basal level of the secreted material from the response fraction by using several iterations. The statistical parameters of the baseline are determined from the values of the basal fractions. A fraction is considered as a response if it is larger or smaller than the $95 \%$ confidence limits of the baseline. Using this program, we analyzed the peaks and calculated the net integral value of the area under the peak (the difference between the total area under the peak and

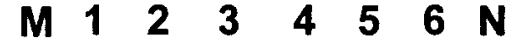

hGHRH-R
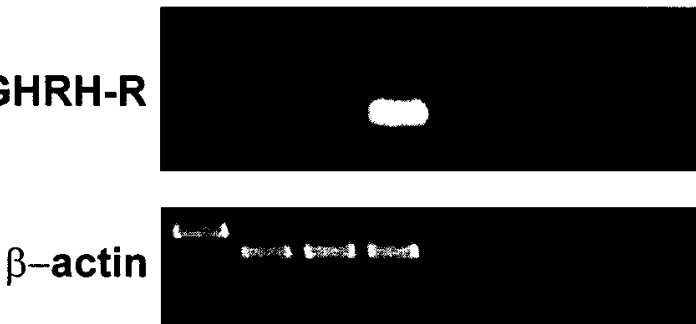

Figure 1 RT-PCR analysis of expression of mRNA for hGHRH-R and $\beta$-actin in $\mathrm{GH} 3$ cells. The products were of the expected size of $144 \mathrm{bp}$ (hGHRH-R) and $542 \mathrm{bp}$ ( $\beta$-actin). Lane $\mathrm{M}, 100 \mathrm{bp}$ DNA molecular mass marker; lane 1, AdAS-infected control GH3 cells; lane 2, intact control GH3 cells; lane 3, AdGHRH-R-infected GH3 cells; lanes 4, 5 and 6, AdAS-infected control, intact control and AdGHRH-R-infected $\mathrm{GH} 3$ cells, without transcription respectively; lane $\mathrm{N}$, negative control, using water as template.

the area under the baseline), representing the net amount of cAMP or GH released by the cells in response to stimuli. The inhibitory activity of GHRH antagonists is expressed as percent inhibition of the reference response. When cAMP or GH responses of the cells to subsequent GHRH stimulations in the control chamber were different from the reference response, percent inhibition was adjusted by the corresponding control response.

\section{Results}

\section{$R T-R C R$ analysis of the AdGHRH-R-infected and control GH3 cells}

The mRNA expression of hGHRH-R and $\beta$-actin in GH3 cells is shown in Fig. 1. The PCR products were of the expected size of $144 \mathrm{bp}$ (hGHRH-R) and $542 \mathrm{bp}$ ( $\beta$-actin). The expression of the hGHRH-R was found only in GH3 cells infected with AdGHRH-R. Control cells infected with AdAS and intact control GH3 cells showed no mRNA expression of the hGHRH-R. PCR products obtained without transcription or using water as a template were also negative (Fig. 1).

\section{cAMP, GH and PRL responses to GHRH in AdGHRH-R-infected GH3 cell cultures}

cAMP levels were measured to evaluate whether the hGHRH-R transferred to GH3 cells by adenoviral vector mediates signal transduction in response to GHRH. Dosedependent increases in cAMP efflux and intracellular cAMP concentration were detected in GH3 cells infected with AdGHRH-R after exposure to $10^{-10}, 10^{-9}$ and $10^{-8} \mathrm{M}$ GHRH for $120 \mathrm{~min}$. GH3 control cells infected with AdAS and intact GH3 cells showed no increases in cAMP in response to GHRH (Fig. 2a and b). 


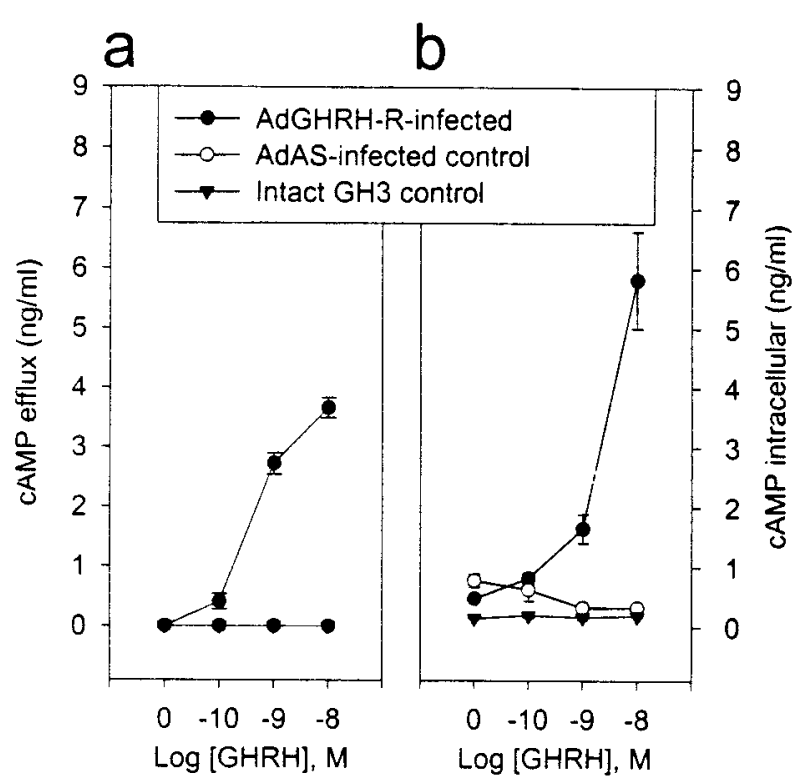

Figure 2 GHRH-stimulated cAMP production in GH3 cell cultures: cAMP efflux (a) and intracellular cAMP accumulation (b) of AdGHRH-R-infected, AdAS-infected control and intact control $\mathrm{GH} 3$ cells after stimulation with increasing doses of GHRH for 120 min. Means \pm S.E.M. of three determinations.

To investigate whether the hGHRH-R transferred to $\mathrm{GH} 3$ cells is able to restore hormone secretion, GH and PRL responses of the cells to GHRH stimulation were evaluated. A dose-dependent increase in GH and PRL secretion was found in the AdGHRH-R-infected GH3 cells at 60 and $120 \mathrm{~min}$ after the addition of increasing doses of GHRH (Fig. 3a). AdAS-infected control and intact control GH3 cells showed no GH or PRL responses to GHRH stimulation (Fig. 3b and c).

Inhibition of stimulated cAMP production and GH secretion by GHRH antagonists in AdGHRH-R-infected GH3 cell cultures

To study the efficacy of GHRH antagonists in competing with GHRH for the hGHRH-R, GH3 cells infected with AdGHRH-R were exposed to GHRH alone or GHRH together with a GHRH antagonist (Fig. $4 \mathrm{a}-\mathrm{c}$ ). GHRH at $10^{-9} \mathrm{M}$ induced a $15 \cdot 7$-fold increase $(P<0 \cdot 001)$ in the cAMP efflux from the GH3 cells infected with AdGHRH-R after $3 \mathrm{~h}$, compared with untreated control cells. Antagonists JV-1-36 and JV-1-38, applied at $3 \times 10^{-8} \mathrm{M}$ concentration, inhibited the GHRHstimulated cAMP efflux from these cells by $80 \cdot 4 \%$ $(P<0 \cdot 001)$ and $36.3 \%(P<0 \cdot 01)$ respectively (Fig. $4 a)$. The intracellular cAMP levels in the hGHRH-R-infected cells were elevated by $103 \%(P<0 \cdot 001)$ after the exposure to GHRH for $3 \mathrm{~h}$. The more potent antagonist, JV-1-36, also inhibited the GHRH-elicited increase in the intracellular cAMP levels by $55 \% \quad(P<0 \cdot 01)$ (Fig. 4b).

Treatment of the AdGHRH-R-infected cells with $10^{-9} \mathrm{M}$ GHRH alone for 1,2 and $3 \mathrm{~h}$ increased the GH secretion by $72 \cdot 8,225$ and $304 \%$ respectively $(P<0 \cdot 001$ compared with untreated controls) (Fig. 4c). The more potent antagonist JV-1-36 abolished the stimulatory effect of GHRH on GH secretion at $1 \mathrm{~h} \quad(P<0 \cdot 001)$, and significantly inhibited it by 63.8 and $73.6 \%$ (both $P<0.001)$ at 2 and $3 \mathrm{~h}$ respectively. Antagonist JV-1-38 was found to be less potent; it suppressed the GHRHstimulated $\mathrm{GH}$ secretion by $20 \cdot 0 \%$ at $1 \mathrm{~h}(P<0 \cdot 01)$ and by $44.9 \%$ at $2 \mathrm{~h}(P<0 \cdot 01)$, and showed no significant effect at $3 \mathrm{~h}$ (Fig. 4c).

\section{cAMP and $G H$ responses to GHRH in a superfusion system}

To study the time-course of cAMP and GH responses to GHRH stimulation, GH3 cells infected with AdGHRH-R were perfused with increasing doses of GHRH, and the amounts of cAMP and GH released from the cells were measured in 3 min fractions (Fig. $5 \mathrm{a}$ and $\mathrm{b}$ ). A perfusion of the AdGHRH-R-infected cells with $10^{-10}, 10^{-9}$ and $10^{-8} \mathrm{M} \mathrm{GHRH}$ for $30 \mathrm{~min}$ at $90 \mathrm{~min}$ intervals induced prompt and dose-dependent increases in the cAMP efflux amounting to $18 \cdot 3,51 \cdot 6$ and $110 \mathrm{ng}$ respectively. The membrane depolarizing $\mathrm{K}^{+}(25 \mathrm{mM}$ $\mathrm{KCl}$ ) did not induce cAMP release (Fig. 5a). Control GH3 cells infected with AdAS and intact control GH3 cells showed no cAMP response to GHRH stimulation (data not shown).

The basal GH secretion of GH3 cells infected with AdGHRH-R was $7 \cdot 99 \pm 0 \cdot 11 \mathrm{ng} / 3 \mathrm{~min}$ (Fig. 5b). The exposure of these cells to $10^{-10}, 10^{-9}$ and $10^{-8} \mathrm{M}$ GHRH for $30 \mathrm{~min}$ at $90 \mathrm{~min}$ intervals induced net increases in the basal $\mathrm{GH}$ secretion of $41 \cdot 3,85.1$ and $97.7 \mathrm{ng}$ respectively. These values represent only 52, 106 and $122 \%$ increases over the basal GH secretion $(79.9 \mathrm{ng} /$ $30 \mathrm{~min})$. The highest dose of GHRH $\left(10^{-8} \mathrm{M}\right)$ induced a somewhat lower GH peak, but more protracted $\mathrm{GH}$ release than the $10^{-9} \mathrm{M}$ dose (Fig. $5 \mathrm{~b}$ ). The perfusion of the cells with the membrane depolarizing $\mathrm{K}^{+}$for $3 \mathrm{~min}$ evoked a release of $24 \cdot 4 \mathrm{ng} \mathrm{GH}$ at the beginning and $9.30 \mathrm{ng}$ at the end of the experiment, indicating that the GH content of the cells was depleted by about $60 \%$ at the end of the experiment (Fig. 5b). GH3 cells infected with AdAS and intact GH3 cells showed no GH response to GHRH stimulation (data not shown). However, a basal $\mathrm{GH}$ secretion at the rate of $21.6 \mathrm{ng} / 3 \mathrm{~min}$ and $14.2 \mathrm{ng} /$ 3 min respectively was seen in these cells.

\section{Inhibition of stimulated cAMP and GH release by GHRH antagonists in a superfusion system}

The inhibitory effect of GHRH antagonists on the hGHRH-R was also evaluated in the superfusion system. 

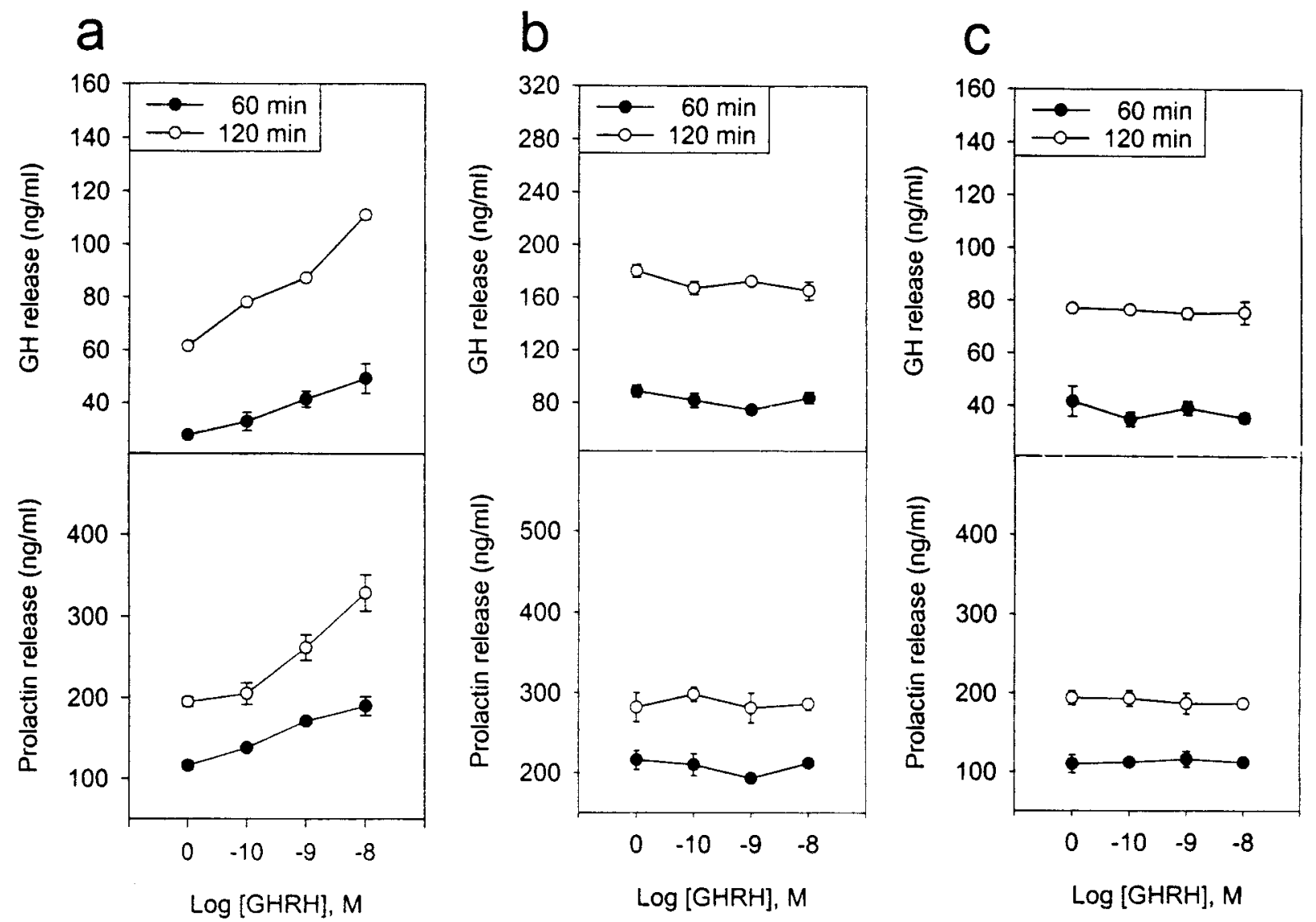

Figure $3 \mathrm{GHRH}$-stimulated $\mathrm{GH}$ and PRL responses in $\mathrm{GH} 3$ cell cultures. GH and PRL release from AdGHRH-R-infected (a), AdAS-infected control (b) and intact control GH3 cells (c) after stimulation with increasing doses of GHRH for 60 and 120 min. Means \pm S.E.M. of three determinations.

AdGHRH-R-infected cells were perfused with GHRH alone (control chamber), or simultaneously with GHRH and GHRH antagonist, and the cAMP and GH responses of the cells were measured (Fig. 6a-c). A repeated perfusion of the AdGHRH-R-infected cells with $10^{-9} \mathrm{M}$ GHRH for $15 \mathrm{~min}$ caused prompt and high increases $(18 \cdot 2 \pm 1.32 \mathrm{ng}$ net release) in the cAMP production. The perfusion of the cells with $\mathrm{KCl}$ did not produce significant changes in the cAMP efflux (Fig. 6a). An exposure of cells to $3 \times 10^{-8} \mathrm{M}$ GHRH antagonist JV-1-36 for $9 \mathrm{~min}$, followed by $15 \mathrm{~min}$ superfusion with JV-1-36 $\left(3 \times 10^{-8} \mathrm{M}\right)$ together with GHRH $\left(10^{-9} \mathrm{M}\right)$, suppressed the cAMP response of the cells by $59 \%$, compared with the first (reference) response to $10^{-9} \mathrm{M} \mathrm{GHRH}$ (Fig. 6b). Following the treatment with JV-1-36, cAMP responses to GHRH were gradually restored, but a $30 \%$ and a $24 \%$ inhibition could still be detected after 60 and 120 min respectively, compared with the reference response (Fig. 6b), adjusted by the corresponding control response (Fig. 6a). The antagonist JV-1-38 was found to be somewhat weaker than JV-1-36 in inhibiting GHRH at $0 \mathrm{~min}$. This antagonist, at $3 \times 10^{-8} \mathrm{M}$ concentration, decreased the GHRH-induced cAMP efflux of the AdGHRH-R-infected cells by $33-37 \%$ at 0,60 and 120 min after administration (not shown). Either antagonist, applied for 9 min prior to GHRH, induced a small increase of the cAMP efflux (less than 15\% compared with the reference response; see Fig. 6b for JV-1-36).

A moderate, but significant stimulation of $\mathrm{GH}$ secretion by repeated perfusion with $10^{-9} \mathrm{M}$ GHRH was observed in the control chamber containing AdGHRH-R-infected cells (not shown). An exposure of the cells to GHRH antagonists JV-1-36 (Fig. 6c) or JV-1-38 (not shown), followed by the superfusion with the antagonist together with GHRH, decreased the GH response by $37-39 \%$, compared with the reference response adjusted by the corresponding control response. No significant inhibition of stimulated GH secretion was seen at 60 or 120 min after exposure to either antagonist. $\mathrm{GH}$ responses to $\mathrm{K}^{+}$were decreased by $45-50 \%$ at the end of the experiment, compared with the initial response, in both the antagonistexposed and the control chamber (Fig. 6c). 

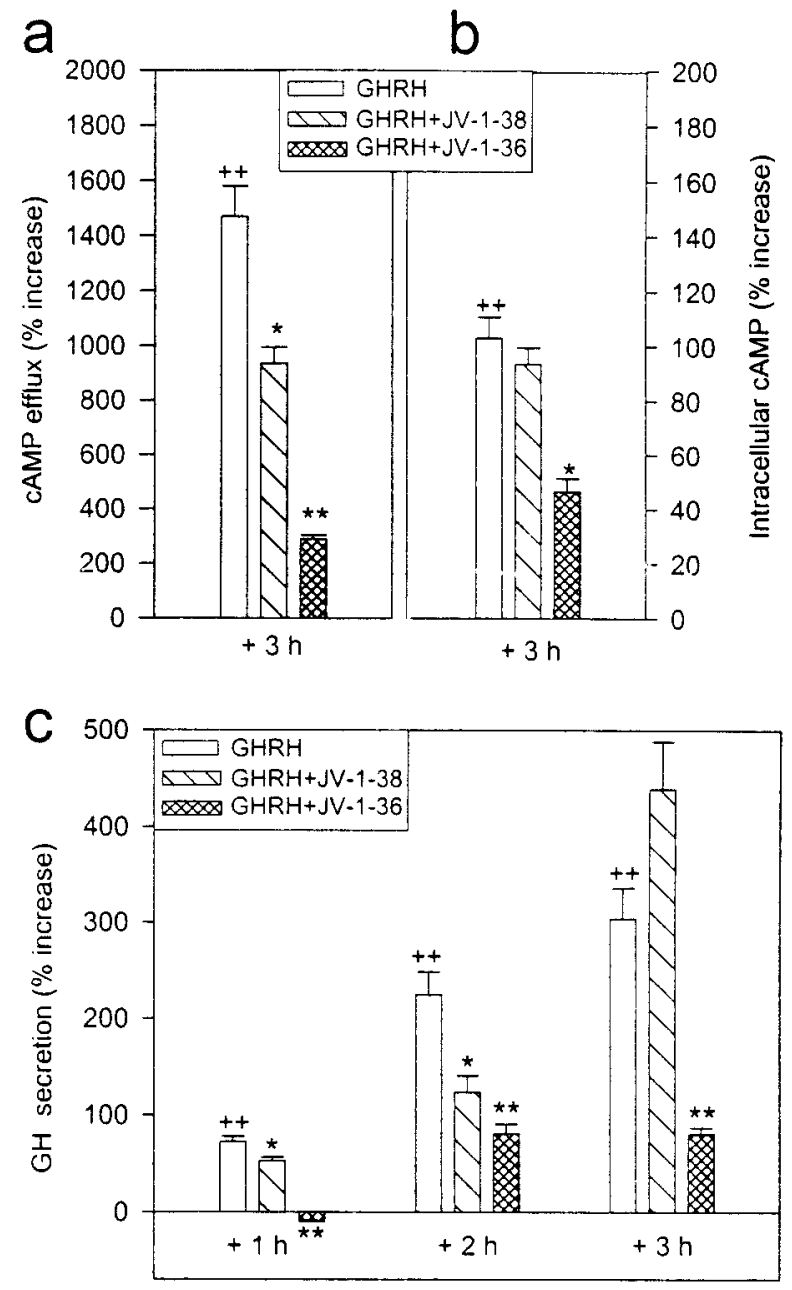

Figure 4 Inhibition of cAMP and GH responses to GHRH by GHRH antagonists in GH3 cell cultures. cAMP efflux (a), intracellular cAMP level (b) and GH secretion (c) of AdGHRH-R-infected $\mathrm{GH} 3$ cells after incubation with $10^{-9} \mathrm{M}$ GHRH alone or GHRH together with $3 \times 10^{-8} \mathrm{M} \mathrm{GHRH}$ antagonist JV-1-36 or JV-1-38 for 1,2 and 3 h. ${ }^{++} P<0 \cdot 001$ vs untreated controls, ${ }^{* *} P<0.001$ vs GHRH, ${ }^{*} P<0.01$ vs GHRH. Means \pm S.E.M. of four determinations.

\section{Discussion}

The GHRH-R, a G-protein coupled receptor, mediates the action of GHRH on pituitary somatotrophs. The binding of GHRH to pituitary cells causes the coupling of the GHRH-R to $G_{s} \alpha$, resulting in the activation of adenylate cyclase. In accord with the view that cAMP is an important second messenger for GHRH signaling, both GHRH and cAMP increase pituitary GH gene expression and stimulate the secretion of $\mathrm{GH}$ and the proliferation of somatotroph cells in the pituitary (Mayo 1992). The hGHRH-R gene is highly homologous to its rat counterpart, encoding a protein that is $82 \%$ identical with the rat
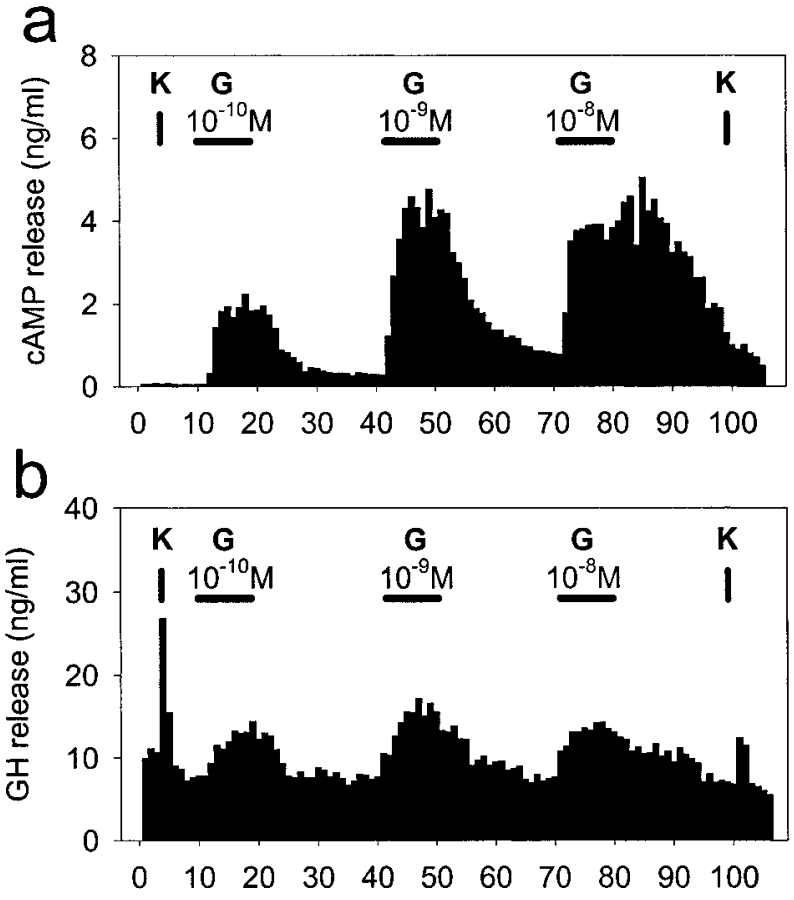

Fractions

Figure 5 cAMP and $\mathrm{GH}$ responses to GHRH of the AdGHRH-R-infected $\mathrm{GH} 3$ cells in the superfusion system. cAMP efflux (a) and $\mathrm{GH}$ secretion (b) induced by repeated administration of GHRH (G) at increasing doses for $30 \mathrm{~min}$ at $90 \mathrm{~min}$ intervals (horizontal bars). Vertical bars indicate $3 \mathrm{~min}$ perfusion with $25 \mathrm{mM} \mathrm{KCl}(\mathrm{K})$, before and after $\mathrm{GHRH}$ stimulations.

GHRH-R protein (Mayo 1992). To study the efficacy of our new GHRH antagonists on the hGHRH-R, we utilized the approach previously developed by Lee et al. (2001) and based on the transfer of the hGHRH-R gene to rat pituitary GH3 cells with adenoviral vectors (Wivel et al. 1999). Using the recombinant adenoviral system, a functional hGHRH-R can be expressed in rat pituitary GH3 cells (Lee et al. 2001). The infection with the AdGHRH-R results in a high mRNA expression of the hGHRH-R gene and the receptor protein, and restores the responsiveness to GHRH (Lee et al. 2001). The present study confirms and extends previous findings by Lee et al. (2001) by demonstrating that GHRH can dose-dependently stimulate cAMP production and GH secretion of the AdGHRH-R-infected cells.

The results obtained from superfusion experiments revealed some differences in the behavior of GH3 cell line, as compared with the normal pituitary somatotrophs (Horvath et al. 1995). Both the control GH3 cells and those expressing GHRH-R showed an elevated level of constitutive GH secretion, but the high cAMP response of the AdGHRH-R-infected cells to GHRH stimulation was not accompanied by a comparably high GH response. 

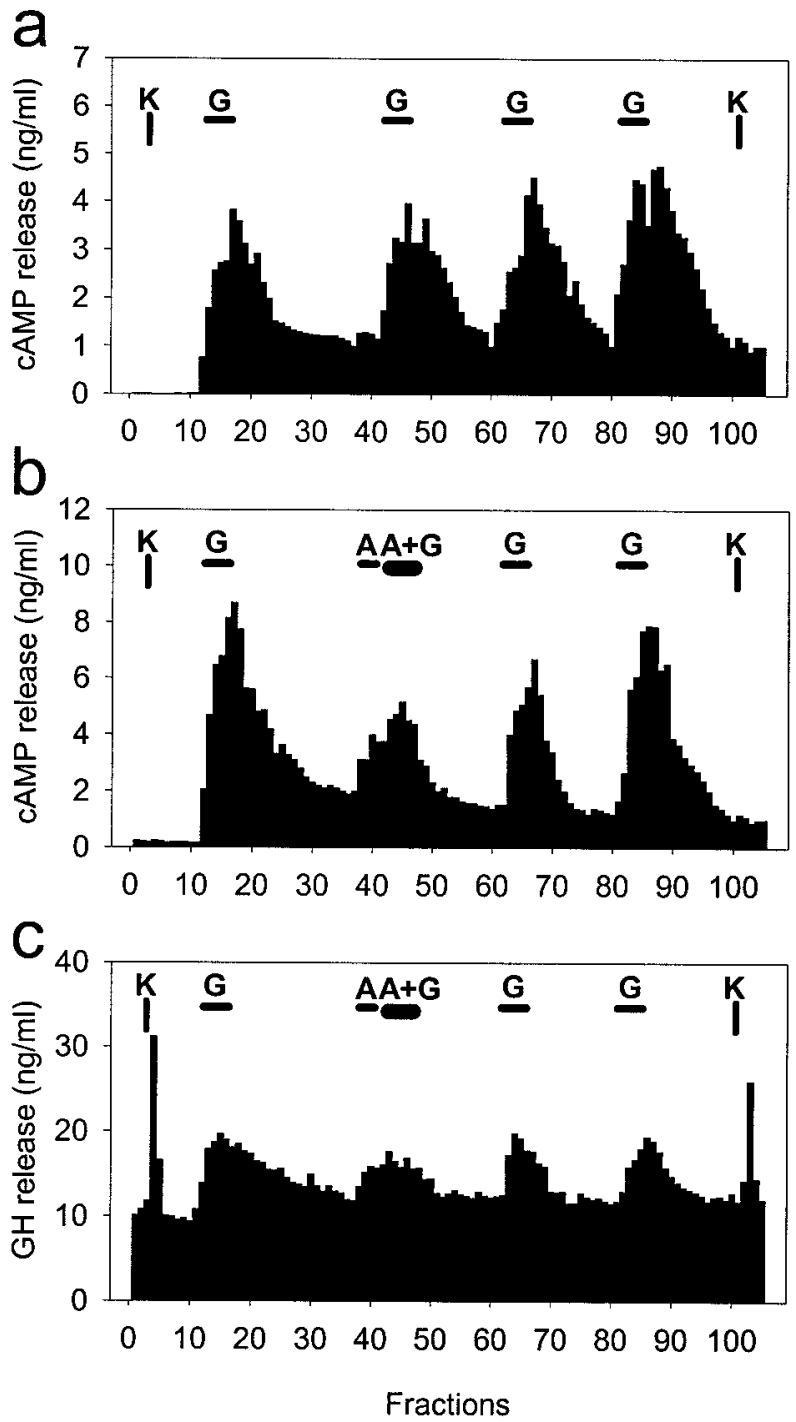

Figure $6 \mathrm{GHRH}$-stimulated cAMP efflux from the AdGHRH-R-infected GH3 cells in the superfusion system, and inhibition of the stimulated cAMP and $\mathrm{GH}$ release by GHRH antagonist JV-1-36. (a) cAMP efflux was induced by repeated administration of $10^{-9} \mathrm{M} \mathrm{GHRH} \mathrm{(G)} \mathrm{for} 15$ min (horizontal bars) in the control chamber. Vertical bars indicate 3 min perfusion with $25 \mathrm{mM} \mathrm{KCl}(\mathrm{K})$, before and after GHRH stimulation. (b) cAMP efflux and (c) $\mathrm{GH}$ release in response to $10^{-9} \mathrm{M} \mathrm{GHRH}$ (G) applied for $15 \mathrm{~min}$ before, during and after administration of $3 \times 10^{-8} \mathrm{M}$ GHRH antagonist JV-1-36 (A). The cells were perfused with JV-1-36 (A) for 9 min (short horizontal bar) followed by a co-perfusion with JV-1-36 and GHRH (A+G) for $15 \mathrm{~min}$ (thick horizontal bar).

Although a prompt release of both cAMP and GH was observed in response to $\mathrm{GHRH}$, indicating that the GH-releasing machinery is working properly in the cells, $\mathrm{GH}$ responses were significantly lower than those of cAMP, and GH was depleted in the cells after stimulation with increasing doses of GHRH. Our results are in agreement with the observations that GH3 cells continuously release synthesized GH and PRL, without storing them in large amounts (Bancroft et al. 1969, Stachura 1982). Therefore, large intracellular pools of $\mathrm{GH}$ are not available for acute exocytosis during the stimulation with GHRH. However, the basal expression of the transcription factor Pit-1, which regulates the gene expression of $\mathrm{GH}$ and PRL, and is also important for cell proliferation in neoplastic pituitary cells, is relatively high in GH3 cell line, in the absence of GHRH stimulation (Zhang et al. 1993, Ying et al. 1999). This may explain the spontaneously high basal GH secretion of GH3 cells.

The inhibitory effects of GHRH antagonists on the rat and mouse pituitary GHRH-R and human tumoral GHRH-R have been demonstrated in several studies (Kovacs et al. 1996, 1997a, 1997b, Schally \& Varga 1999, Varga et al. 1999, Schally et al. 2001). After the design and synthesis, our GHRH antagonists are characterized on the basis of in vitro and in vivo endocrine assays on rat pituitaries and oncological tests. These oncological tests carried out in human cancer lines xenografted into nude mice or in vitro revealed that some of the effects of the GHRH antagonists must be exerted directly on tumors. Nevertheless, a series of attempts in our laboratory failed to detect the pituitary form of GHRH-R in human cancer models (Schally \& Varga 1999). Subsequent work revealed that specimens of some primary human tumors, such as prostate and lung cancers, and various human cancer cell lines expressed the mRNAs corresponding to four truncated splice variants of GHRH-R, denoted $\mathrm{SV}_{1}$ to $\mathrm{SV}_{4}$, whereas the full-length pituitary receptor form was not expressed (Halmos et al. $2000,2002) . \mathrm{SV}_{1}$ appears to be the major isoform of GHRH-R expressed in neoplastic tissues, which may mediate the antiproliferative effect of GHRH antagonists (Halmos et al. 2000, 2002, Rekasi et al. 2000a). Although the tumoral GHRH-R appears to be different from those in the pituitary, the tumor inhibition induced by GHRH antagonists is nevertheless exerted in part by an indirect mechanism based on suppression of GH release from the pituitary and the reduction in hepatic production of IGF-I (Schally et al. 2001). Because endocrine tests were carried out using rat pituitaries and GHRH antagonists were developed for clinical applications, it was important to establish the efficacy of these antagonists on the human pituitary receptor as the rat pituitary GHRH-R shows an $18 \%$ difference in the amino acid sequence as compared with its human counterpart (Mayo 1992). Our findings from both cell culture and superfusion experiments show that GHRH antagonists JV-1-36 and JV-1-38 effectively inhibit the actions of GHRH on the hGHRH-R. The more potent antagonist JV-1-36 totally prevented the stimulatory effect of hGHRH on GH secretion after $1 \mathrm{~h}$ and suppressed the stimulated $\mathrm{GH}$ secretion by $64-74 \%$ after $2-3 \mathrm{~h}$ in GH3 cells expressing the hGHRH-R. The other antagonist, JV-1-38, also significantly inhibited the stimulatory action of GHRH, but was less potent. A small 
intrinsic agonistic activity of JV-1-36 and JV-1-38 was observed in the superfusion, but not in the tissue cultures. In addition, the short-term inhibitory effects of these antagonists in the superfusion system were found to be somewhat weaker than their long-term actions in the GH3 cell cultures. These findings can be explained by the different sensitivity of the two test systems to GHRH peptides. Because in the superfusion experiments we used a number of hGHRH-R-infected GH3 cells 25 times greater than for the cell cultures, the former system was more sensitive than the latter and it could reveal a weak intrinsic activity of the GHRH antagonists. The suppression of GHRH-stimulated GH secretion by these antagonists was accompanied by a parallel suppression of cAMP production, indicating that both effects are mediated by the hGHRH-R. Thus our GHRH antagonists are active not only on rat and mouse pituitary GHRH-Rs, and in $3 \mathrm{~T} 3$ fibroblasts transfected with $\mathrm{SV}_{1}$ variant of human tumoral GHRH-R (Kiaris et al. 2002), but also on human pituitary GHRH-R expressed in GH3 cells, as demonstrated in the present study.

The inhibitory activities of JV-1-36 and JV-1-38 observed in GH3 cells expressing the hGHRH-R correspond to those found in previous work on normal rat pituitary cells expressing the rat GHRH-R (Varga et al. 1999). In that study, JV-1-36 used at the same dose as in the present work showed a high and protracted antagonistic activity in vivo and in vitro, and its inhibitory effect on the stimulated $\mathrm{GH}$ secretion also exceeded that of JV-1-38. Thus GHRH antagonists JV-1-36 and JV-1-38 exhibit a similar spectrum of activity on the hGHRH-R and the rat GHRH-R. Our previous study in rats also revealed that antagonist JV-1-36 is about 70 times more potent and longer acting than the GHRH antagonist $\left[\mathrm{Ac}-\mathrm{Tyr}^{1}, \mathrm{D}-\mathrm{Arg}^{2}\right] \mathrm{hGHRH}(1-29) \mathrm{NH}_{2}$ (Varga et al. 1999).

In conclusion, this study reports dose-dependent stimulatory effects of GHRH on the production and extracellular release of cAMP, as well as on the secretion of $\mathrm{GH}$ and PRL, in rat pituitary GH3 cells subjected to hGHRH-R gene transfer by adenoviral vector. Our work also demonstrates for the first time the ability of GHRH antagonists JV-1-36 and JV-1-38 to inhibit the action of GHRH on the hGHRH-R. An inhibition by GHRH antagonist JV-1-36 of the hGHRH-R-mediated effects of hGHRH indicates that this class of compounds might be useful in a clinical setting for the treatment of tumors that are influenced by circulating IGF-I levels.

\section{Acknowledgements}

We thank Dr A F Parlow and the National Hormone and Pituitary Program, the National Institute of Diabetes and Digestive and Kidney Diseases, for RIA reagents. This work was supported by the Medical Research Service of
Veterans Affairs Department, and by a grant from Zentaris AG (Frankfurt am Main, Germany) to Tulane University School of Medicine (all to A V S).

\section{References}

Bancroft FC, Levine L \& Tashjian AH Jr 1969 Control of growth hormone production by a clonal strain of rat pituitary cells. Stimulation by hydrocortisone. Journal of Cell Biology 43 432-441.

Chan JM, Stampfer MJ, Giovannucci E, Gann PH, Ma J, Wilkinson P, Hennekens CH \& Pollak M 1998 Plasma insulin-like growth factor-I and prostate cancer risk: a prospective study. Science 279 563-566.

Clark RG \& Robinson ICAF 1985 Growth induced by pulsatile infusion of an amidated fragment of growth hormone-releasing factor in normal and GHRF-deficient rats. Nature 314 281-283.

Csernus VJ \& Schally AV 1991 The dispersed cell superfusion system. In Neuroendocrine Research Methods, pp 71-109. Ed BD Greenstein. London: Harwood Academic Publishers.

Csernus VJ, Schally AV \& Groot K 1999 Antagonistic analogs of growth hormone-releasing hormone (GHRH) inhibit cyclic AMP production of human cancer cell lines in vitro. Peptides 20 843-850.

Halmos G, Schally AV, Varga JL, Plonowski A, Rekasi Z \& Czompoly T 2000 Human renal cell carcinoma expresses distinct binding sites for growth hormone-releasing hormone. PNAS 97 10555-10560.

Halmos G, Schally AV, Czompoly T, Krupa M, Varga JL \& Rekasi Z 2002 Expression of growth hormone-releasing hormone (GHRH) and its receptor splice variants in human prostate cancer. Journal of Clinical Endocrinology and Metabolism (In Press).

Horvath J, Groot K \& Schally AV 1995 Growth hormone-releasing hormone stimulates cAMP release in superfused rat pituitary cells. PNAS 92 1856-1860.

Jaffe CA, DeMott-Friberg R, Frohman LA \& Barkan AL 1997 Suppression of growth hormone $(\mathrm{GH})$ hypersecretion due to ectopic GH-releasing hormone (GHRH) by a selective GHRH antagonist Journal of Clinical Endocrinology and Metabolism 82 634-637.

Kahan Z, Arencibia J, Csernus V, Groot K, Kineman R, Robinson WR \& Schally AV 1999 Expression of growth hormone-releasing hormone (GHRH) messenger ribonucleic acid and the presence of biologically active GHRH in human breast, endometrial, and ovarian cancers. Journal of Clinical Endocrinology and Metabolism $\mathbf{8 4}$ 582-589.

Kahan Z, Varga JL, Schally AV, Rekasi Z, Armatis P, Chatzistamou I, Czompoly T \& Halmos G 2000 Antagonists of growth hormonereleasing hormone arrest the growth of MDA-MB-468 estrogenindependent human breast cancers in nude mice. Breast Cancer Research and Treatment 60 71-79.

Kiaris H, Schally AV, Varga JL, Groot K \& Armatis P 1999 Growth hormone-releasing hormone: an autocrine growth factor for small cell lung carcinoma. PNAS 96 14894-14898.

Kiaris H, Schally AV, Busto R, Halmos G, Artavanis-Tsakonas S \& Varga JL 2002 Expression of a splice variant of the receptor for GHRH in 3T3 fibroblasts activates cell proliferation responses to GHRH analogs. PNAS 99 196-200.

Kovacs M, Fancsik A, Mezo I, Teplan I \& Flerko B 1994 Effects of continuous and repetitive administration of a potent analog GHRH(1-30) $\mathrm{NH}_{2}$ on the GH release in rat. Neuroendocrinology $\mathbf{5 9}$ 371-379.

Kovacs M, Zarandi M, Halmos G, Groot K \& Schally AV 1996 Effects of acute and chronic administration of a new potent antagonist of growth hormone-releasing hormone in rats: mechanisms of action. Endocrinology 137 5364-5369.

Kovacs M, Kineman RD, Schally AV, Zarandi M, Groot K \& Frohman LA 1997a Effects of antagonists of growth hormone-releasing hormone (GHRH) on GH and insulin-like 
growth factor-I levels in transgenic mice overexpressing the human GHRH gene, an animal model of acromegaly. Endocrinology 138 4536-4542.

Kovacs M, Schally AV, Zarandi M \& Groot K $1997 b$ Inhibition of $\mathrm{GH}$ release in rats by new potent antagonists of growth hormone-releasing hormone (GH-RH). Peptides 18 431-438.

Kovacs M, Schally AV, Csernus B, Busto R, Rekasi Z \& Nagy A 2002 Targeted cytotoxic analogue of luteinizing hormone-releasing hormone (LH-RH) only transiently decreases the gene expression of pituitary receptors for LH-RH. Journal of Neuroendocrinology 14 5-13.

Lamharzi N, Schally AV, Koppan AV, Koppan M \& Groot K 1998 Growth hormone-releasing hormone antagonist MZ-5-156 inhibits growth of DU-145 human androgen-independent prostate carcinoma in nude mice and suppresses the level and mRNA expression of insulin like growth factor II in tumors. PNAS 95 8864-8868.

Lee EJ, Anderson LM, Thimmapaya B \& Jameson JL 1999 Targeted expression of toxic genes directed by pituitary hormone promoters: a potential strategy for adenoviral-mediated gene therapy of pituitary tumors. Journal of Clinical Endocrinology and Metabolism 84 786-794.

Lee EJ, Duan R, Kotlar T \& Jameson JL 2001 Restoration of growth hormone-releasing hormone (GHRH) responsiveness in pituitary GH3 cells by adenovirus-directed expression of the human GHRH receptor. Endocrinology 142 414-420.

Mayo KE 1992 Molecular cloning and expression of a pituitaryspecific receptor for growth hormone-releasing hormone. Molecular Endocrinology 6 1734-1744.

Mayo KE, Hammer RE, Swanson JW, Brinster RL, Rosenfeld MG \& Evans RM 1988 Dramatic pituitary hyperplasia in transgenic mice expressing a human growth hormone-releasing factor gene. Molecular Endocrinology 2 606-612.

Mayo KE, Godfrey PA, Suhr ST, Kulik DJ \& Rahal JO 1995 Growth hormone-releasing hormone. Synthesis and signaling. In Recent Progress in Hormone Research, pp 35-73. Ed. CW Bardin. San Diego, CA: Academic Press.

Pinski J, Schally AV, Groot K, Halmos G, Szepeshazi K, Zarandi M \& Armatis P 1995 Inhibition of growth of human osteosarcomas by antagonists of growth hormone-releasing hormone. Journal of the National Cancer Institute 87 1787-1794.

Rekasi Z, Czompoly T, Schally AV \& Halmos G 2000a Isolation and sequencing of $\mathrm{cDNAs}$ for spice variants of growth hormonereleasing hormone receptors from human cancers. PNAS $\mathbf{9 7}$ 10561-10566.

Rekasi Z, Varga JL, Schally AV, Halmos G, Armatis P, Groot K \& Czompoly T $2000 b$ Antagonists of growth hormone-releasing hormone and vasoactive intestinal peptide inhibit tumor proliferation by different mechanisms: evidence from in vitro studies in human prostatic and pancreatic cancers. Endocrinology 141 2120-2128.

Rekasi Z, Varga JL, Schally AV, Plonowski A, Halmos G, Csernus B, Armatis P \& Groot K 2001 Antiproliferative actions of growth hormone-releasing hormone antagonists on MiaPaCa-2 human pancreatic cancer cells involve cAMP independent pathways. Peptides 22 879-886.

Robberecht P, Coy DH, Waelbroeck M, Heiman ML, de Neef P, Camus JC \& Christophe J 1985 Structural requirements for the activation of rat anterior pituitary adenylate cyclase by growth hormone-releasing factor (GRF): discovery of (N-Ac-Tyr1, D-Arg2)-GRF(1-29)- $\mathrm{NH}_{2}$ as a GRF antagonist on membranes. Endocrinology 117 1759-1764.

Schally AV \& Varga JL 1999 Antagonistic analogs of growth hormone-releasing hormone: new potential antitumor agents. Trends in Endocrinology and Metabolism 10 383-391.

Schally AV, Comaru-Schally AM, Nagy A, Kovacs M, Szepeshazi K, Plonowski A, Varga JL \& Halmos G 2001 Hypothalamic hormones and cancer. Frontiers in Neuroendocrinology 22 248-291.

Stachura ME 1982 Sequestration of an early-release pool of growth hormone and prolactin in GH3 rat pituitary tumor cells. Endocrinology 111 1769-1777.

Szepeshazi K, Schally AV, Groot K, Armatis P, Halmos G, Hebert F, Szende B, Varga JL \& Zarandi M 2000a Antagonists of growth hormone-releasing hormone (GHRH) decrease IGF-II production of HT-29 human colon cancer cells and inhibit tumor growth. British Journal of Cancer 82 1724-1731.

Szepeshazi K, Schally AV, Groot K, Armatis P, Hebert F \& Halmos G $2000 b$ Antagonists of growth hormone-releasing hormone (GHRH) inhibit in vivo proliferation of experimental pancreatic cancers and decrease IGF-II levels in tumors. European Journal of Cancer 36 128-136.

Thorner MO, Reschke J, Chitwood J, Rogol AD, Furlanetto R, Rivier J, Vale V \& Blizzard RM 1985 Acceleration of growth in two children treated with human growth hormone-releasing factor. New England Journal of Medicine 312 4-9.

Varga JL, Schally AV, Csernus JV, Zarandi M, Halmos G, Groot K \& Rekasi Z 1999 Synthesis and biological evaluation of antagonists of growth hormone-releasing hormone with high and protracted in vivo activities. PNAS 96 692-697.

Wivel MM, Gao GP \& Wilson JM 1999 Adenoviral vectors. In The Development of Human Gene Therapy, pp 87-110. Ed. T Friedman. Cold Spring Harbor, NY: Cold Spring Harbor Laboratory Press.

Ying C, Lin DH, Sarkar DK \& Chen TT 1999 Interaction between estrogen receptor and Pit-1 protein is influenced by estrogen in pituitary cells. Journal of Steroid Biochemistry and Molecular Biology 68 145-152.

Zhang K, Kulig E, Jin L \& Lloyd RV 1993 Effects of estrogen and epidermal growth factor on prolactin and Pit-1 mRNA in GH3 cells. Proceedings of the Society for Experimental Biology and Medicine 202 193-200.

Received in final form 26 July 2002

Accepted 29 July 2002 